To Maega $\mid$ Jurnal Pengabdian Masyarakat

Februari 2022, Vol.5, No.1, hal, 63-74

$\operatorname{ISSN}(P): 2622-6332 ; \operatorname{ISSN}(E): 2622-6340$

http://www.ojs.unanda.ac.id/index.php/tomaega

\title{
Pendidikan Kesehatan Meningkatkan Pengetahuan dan Sikap Pencegahan Covid-19 pada Siswa SMP
}

\author{
Siti Fadlilah ${ }^{1}$, Cornelia Dede Yoshima Nekada ${ }^{2}$, Fiorentina Marsela Maturbongs ${ }^{3}$
}

${ }_{1}^{1}$ Program Studi Pendidikan Profesi Ners, Universitas Respati Yogyakarta

2-3 Program Studi Sarjana Keperawatan, Universitas Respati Yogyakarta 1 Program Studi,

*Correspondent Email: sitifadlilah@respati.ac.id

Article History:

Received: 08-11-2021; Received in Revised: 16-12-2021; Accepted: 20-12-2021

DOI: http://dx.doi.org/10.35914/tomaega.v5i1.953

\begin{abstract}
Abstrak
Coronavirus Disease 2019 (COVID-19) merupakan penyakit baru yang belum pernah diidentifikasi pada manusia. COVID-19 dapat dicegah dengan pengetahuan dan sikap yang baik, seperti memberikan pendidikan kesehatan di lingkungan sekolah. Kegiatan pendidikan kesehatan diberikan pada tanggal 24 April 2021 secara online melalui zoominar. Pendidikan kesehatan dilakukan satu kali selama 30 menit. Jumlah peserta sebanyak 42 orang yang dibagi rata menjadi kelompok kontrol dan intervensi. Pengetahuan dan sikap diukur pretest dan posttest. Pada kelompok kontrol dan intervensi menunjukkan kenaikan rata-rata pengetahuan nilai saat posttest.Pada kelompok kontrol terjadi penurunan nilai mean sikap saat posttest, sedangkan kelompok intervensi menunjukkan adanya kenaikan mean sikap saat posttest. Hasil statistik menunjukkan pada kelompok kontrol tidak ada perbedaan pengetahuan pretest dan posttest, $p$-value 0,39. Ada perbedaan sikap pretest dan posttest pada kelompok kontrol (p-value 0,012), perbedaan terjadi dilihat dari penurunan nilai sikap. Kelompok intervensimenunjukkan ada perbedaan pengetahuan dan sikap pretest dan posttest, p-value 0,009 dan 0,002. Pemberian pendidikan kesehatan terbukti meningkatkan pengetahuan tentang COVID-19 dan sikap siswa tentang pencegahan COVID-19. Upaya promosi kesehatan diperlukan untuk mengoptimalkan fungsi preventif dan promotif melalui pendidikan kesehatan.
\end{abstract}

Kata Kunci: Corona; Covid-19; Pendidikan Kesehatan

\begin{abstract}
Coronavirus Disease 2019 (COVID-19) is a new disease that has never been identified in humans. COVID-19 can be prevented with good knowledge and attitude, such as providing health education in the school environment. Health education activities will be given 30 minutes on April 24, 2021, online through zooming. The number of participants was 42 people who were divided equally into control and intervention groups. Knowledge and attitudes were measured pretest and posttest. The control and intervention groups showed an increase in the average knowledge value at the posttest. There was a decrease in mean attitude at the posttest in the control group, while the intervention group showed an increase in the mean attitude at the posttest. Statistical results showed that there was no difference in pretest and posttest knowledge in the control group, p-value 0.39. There was a difference in the attitude of the pretest and posttest in the control group ( $p$-value 0.012). The difference was seen from the decrease in the attitude value. The intervention group showed differences in knowledge and attitudes between pretest and posttest, p-
\end{abstract}


values of 0.009 and 0.002 . The provision of health education has been proven to increase understanding about COVID-19 and student attitudes about COVID-19 prevention. Health promotion efforts are needed to optimize preventive and promotive functions through health education.

Key Word: Corona; Covid-19; Health Education

\section{Pendahuluan}

Menurut data dari Kementrian Kesehatan Republik Indonesia (2021), jumlah kasus konfirmasi pada 1 September 2021 di Indonesia sebanyak 4.079.267 dan 132.491 kasus meninggal (3,2\%), kasus sembuh $3.743 .716(91,8 \%)$, dan kasus aktif 203.060 (5,0\%). Kabupaten Kota terdampak 510 dan Transmisi lokal 315. Provinsi DKI Jakarta menjadi Provinsi dengan tingkat kasus COVID-19 terbanyak di Indonesia 851.256 kasus yang terkonfrimasi, jawa barat 692.178, Jawa Tengah 470.278, Jawa Timur 384.374, Kalimanatan Timur 151.235 dan Yogyakarta 150.388.

Yogyakarta menjadi salah satu provinsi terdampak penyebaran COVID-19. Awal perkembangan COVID-19 dari warga yang kontak dengan penderita di luar daerah dan menyebar melalui transmisi lokal. Penyebaran diperparah dengan rendahnya kesadaran masyarakat menerapkan protokol pencegahan COVID-19 (Witono\&Suparna, 2020). Pendatang dari luar wilayah terjangkit yang tidak jujur dan tidak disiplin melakukan isolasi mandiri. Menurut data yang diambil dari Yogyakarta Tanggap COVID-19(2020), pada 01 September 2021 Angka kejadian di DIY, terdapat jumlah kasus 149.379 kasus konfirmasi jumlah kasus yang sembuh $132.776(66,33 \%)$, jumlah kasus meninggal 4.849 (1,94\%), dan yang dirawat 12.293 (31.72\%). Angka kejadian di Kabupaten Sleman sebanyak 37.087 orang dengan rincian pasien yang meninggal 156 orang, dan yang sembuh 6.518 orang.

Penularan COVID-19 melalui system pernapasan melalui droplet. Penularan dapat melalui kontak langsung dan tidak langsung. Kontak langsung terjadi bila penderita batuk atau bersin kemudian mengenai orang lain. Jarak kurang dari 1 meter dengan penderita meningkatkan resiko penularan. Penularan tidak langsung terjadi ketika droplet menempel ke benda dan disentuh orang lain. Droplet tersebut apbila menyentuh wajah, hidung, atau mata akan membuat virus masuk ke dalam tubuh (Kementrian Kesehatan Republik Indonesia, 2020).

Ganasnya penularan COVID-19 dapat dihindari dengan menerapkan disiplin protokol pencegahan COVID-19. Perilaku kesehatan tersebut antara lain memakai masker, memakai face shield, mencuci tangan dengan sabun atau hand sanitizer, menjaga jarak, dan menerapkan etika batuk dan bersin yang benar. Hindari memegang area wajah dengan tangan sebelummencucinya terlebih dahulu, terutama area hidung dan mulut (Susilo et al., 2020).

Sekolah menerapkan sistem pembelajaran melalui daring masa pandemi COVID-19. Pada masa pandemi siswa harus melakukan pembelajaran dirumah agar tidak terpapar dengan banyak orang sehingga dapat mencegah rentang 
terkena COVID-19. Sistem pembelajaran melalui daring mempunyai banyak kelemahan, tujuan pembelajaran menjadi jauh dari target yang diharapkan. Meskipun begitu, metode daring tetap dipilih agar proses belajar siswa tetap berjalan (Pratama \& Mulyati, 2020).

Adanya pengetahuan dan sikap yang baik dapat mencegah penyebaran COVID-19. Pengetahuan dan sikap yang baik dapat diperoleh dengan memberikan edukasi melalui pendidikan kesehatan di lingkungan sekolah. Pendidikan kesehatan untuk meningkatkan pengetahuan melalui mata dan telinga (Usman et al., 2020). Pemberian pendidikan kesehatan dapat meningkatkan pengetahuan bagaimana cara menerapkan pencegahan COVID-19 di lingkungan sekolah dan sikap yang baik. Dari pengetahuan dan sikap yang baik siswa dapat menerapkan pencegahan COVID-19. Sehingga dengan sikap yang baik dapat merespon aktivitas belajar pendidikan kesehatan yang bermanfaat bagi dirinya sendiri dan lingkungan sekolah. Kegiatan ini bertujuan untuk meningkatkan pengetahuan dan sikap siswa tentang pencegahan COVID-19.

\section{Metode}

\subsection{Pembuatan Media dan Instrumen Pendidikan Kesehatan}

Instrumen yang digunakan dibuat oleh peneliti sesuai dengan teori dan dilakukan uji validitas kepada penguji expert. Nilai dari penguji expert didapatkan rata 0,82 , berarti instrumen layak digunakan. Kuesionar pengetahuan tentang Covid-19 dan sikap pencegahan Covid-19 masingmasing sebanyak 20 pernyataan dengan pilihan jawaban menggunakan skala likert. Pernyataan terdiri favourable dan unfavourable. Media yang digunakan power point presentation dengan materi tentang Covid-19 sebanyak 20 slide.

\subsection{Pembuatan Grup Aplikasi Whatsapp Messenger}

Pemateri membuat dua grup untuk membedakan sesuai dengan pembagian kelompok yaitu grup untuk kelompok kontrol dan intervensi, Grup digunakan untuk mengirimkan informasi terkait kegiatan pendidikan kesehatan. Kriteria peserta pendidikan kesehatan yaitu bersedia, dalam keadaan sehat, dan belum pernah mendapatkan pendidikan kesehatan tentang Covid-19. Peserta dibagi menjadi 2 kelompok yaitu kelompok intervensi dan kelompok Kontrol. Jumlah peserta setiap kelompok sebanyak 21 orang.

\subsection{Pelaksanaan Pendidikan Kesehatan}

Pendidikan kesehatan yang diberikan merupakan suatu tindakan memberikan informasi pada siswa SMP kelas VIII tentang pencegahan COVID-19 yang terdiri dari Definisi, Tanda dan Gejala Penyebab, karateristik COVID-19, dan pencegahan COVID-19. Pendidikan kesehatan dilakukan sekali dalam waktu 30 menit. Pendidikan kesehatan dilakukan secara daring melalui media zoom pada siswa SMP Negeri 2 Depok Sleman. SMP Negeri 2 Depok Sleman beralamat di Jalan Dahlia, Dero, 
Condongcatur, Kecamatan Depok, Kabupaten Sleman, Daerah Istimewa Yogyakarta. Pendidikan kesehatan dilaksanakan 24 April 2021.

\subsection{Proses Pengambilan dan Analisis Data}

Pengetahuan tentang pencegahan COVID-19 dan sikap tentang pencegahan COVID-19 diukur menggunakan kuesioner. Data terdiri dari pretest dan posttest. Data pretest kelompok intervensi diambil 10 menit sebelum dilakukan pendidikan kesehatan. Data posttest diambil langsung setelah intervensi selesai. Data pretest dan posttest kelompok kontrol diambil bersamaan waktu dengan kelompok intervensi. Pendidikan kesehatan pada kelompok kontrol dilakukan setelah peserta mengisi kuesioner posttest untuk menerapkan prinsip keadilan kepada semua peserta. Data dianalisis menggunakan distribusi frekuensi, Paired t-test, dan Uji Wilcoxon.

\section{Hasil dan Pembahasan}

\subsection{Gambaran Lokasi}

SMP Negeri 2 Depok Sleman memiliki 3 kelas yaitu kelas 7, 8 dan kelas 9 . Jumlah kelas 7 seangkatan 126 siswa, kelas 8 seangkatan 143 siswa dan kelas 9 seangakatan terdapat 127 siswa. Branded SMP Negeri 2 Depok Sleman yaitu "BERANI BERPRESTASI". Untuk meminimalisirkan penyebaran COVID-19, dalam masa pandemi COVID-19 siswa-siswi SMP Negeri 2 Depok Sleman masih tetap sekolah namun masih via Online. Program pencegahan COVID-19 dilakukan di sekolah adalah melaksanakan protokol kesehatan Gerakan 5M antara lain memakai masker, mencuci tangan, menjaga jarak, menjauhi kerumunan serta membatasi mobilisasi dan interaksi

\subsection{Karakteristik Responden}

Tabel 1 Distribusi Frekuensi Karaktersitik Responden

\begin{tabular}{lcccc}
\hline \multicolumn{1}{c}{ Karateristik } & \multicolumn{2}{c}{ Kontrol } & \multicolumn{2}{c}{ Intervensi } \\
\cline { 2 - 5 } \multicolumn{1}{c}{ Responden } & f & f & f & \% \\
\hline Laki-laki & 8 & 38,1 & 12 & 57,1 \\
Perempuan & 13 & 61,9 & 9 & 42,9 \\
\hline Usia & 2 & & & \\
13 & 16 & 9,5 & 3 & 14,3 \\
14 & 3 & 76,2 & 17 & 81,0 \\
15 & & 14,3 & 1 & 4,8 \\
\hline Kelas & 8 & & & \\
VIII A & 13 & 38,1 & 12 & 57,1 \\
VIII B & 61,9 & 9 & 42,9 \\
\hline
\end{tabular}

Tabel 1 diketahui jenis kelamin responden kelompok kontrol yang paling banyak perempuan sebanyak 13 orang $(61,9 \%$. Kelompok intervensi paling banyak responden laki-laki sebanyak 12 orang $(57,1 \%)$. Mayoritas responden kelompok kontrol dan intervensi berumur 14 tahun yaitu 16 orang $(76,2 \%)$ dan17 orang $(81,0 \%)$. Peserta kelompok kontrol sebagian besar kelas VIII B sebanyak 13 
orang $(61,9 \%)$. Peserta kelompok intervensi sebagian besar kelas VIIIA sebanyak 12 orang $(57,1 \%)$.

\subsection{Hasil Pengetahuan tentang Covid-19 Saat Pretest dan Posttest}

Tabel 2 Pengetahuan tentang COVID-19 Pada Siswa SMP Negeri 2 Depok

\begin{tabular}{lccccc}
\multicolumn{5}{c}{ Sleman } \\
\hline \multicolumn{1}{c}{ Pengetahuan } & $\Sigma$ & Min & Max & Mean & SD \\
\hline Kelompok Kontrol & & & & & \\
Pretest & 21 & 11,00 & 17,00 & 15,09 & 1,12 \\
Posttest & 21 & 14,00 & 17,00 & 15,57 & 1,57 \\
\hline Kelompok Intervensi & & & & & \\
Pretest & 21 & 12,00 & 19,00 & 15,04 & 1,33 \\
Posttest & 21 & 13,00 & 17,00 & 15,23 & 1,59 \\
\hline
\end{tabular}

Tabel 2 Pengetahuan tentang pencegahan COVID-19 pretest pada kelompok kontrol didapatkan mean 15,09 dan pada kelompok intervensi 15,04. Pengetahuan pretest pada penelitian ini yaitu kemampuan siswa untuk mengetahui tentang pencegahan COVID-19 dimana untuk mengetahui kemampuan awal siswa mengenai materi yang disampaikan.

Kurangnya informasi tentang COVID-19 menjadi salah satu faktor yang berhubungan dengan rendahnya nilai pretest yang didapatkan peserta. Peserta memang sengaja dipilih yang belum pernah mendapatkan informasi atau pendidikan kesehatan tentang COVID-19. Peserta juga sebatas mengetahui tentang COVID-19 dari media sosial. Pengetahuan merupakan hasil "tahu" dan ini terjadi setelah orang mengadakan pengindaraan terhadap suatu objek tertentu (Wawan \& Dewi, 2010). Sumber pengetahuan juga melalui hasil melihat, mendengar dari sumber pengetahuan seperti pengajar atau media lain. Pengetahuan juga dapat ditingkatkan melalui pemberian Pendidikan Kesehatan. Adanya pengetahuan yang baik siswa-siswi akan memiliki informasi tentang dampak baik dan buruk melanggar protokol pencegahan COVID-19 sebelum melanggar sehingga siswa-siswi dapat lebih berpikir mengenai resiko kesehatannya.

Semua peserta semua kelompok mengetahui singkatan COVID-19 dan berasal dari China. Menurut Kementrian Kesehatan Republik Indonesia (2020), COVID-19 adalah singkatan Coronavirus Disease 2019 dan diberi nama SarsCoV-2. Peserta semua kelompok juga mengetahui demam, batuk, flu dan sesak napas sebagai tanda dan gejala COVID-19. Menurut Mindiharto (2020), terdapat tanda dan gejala umum terinfeksi virus COVID-19 yaitu demam sampai dengan $37,5^{\circ} \mathrm{C}$. Demam merupakan gejala lain akibat kondisi mendasari beberapa diantaranya batuk, flu dan disertai sesak napas.

Seluruh peserta mengetahui pencegahan Covid-19 dapat dilakukan dengan mencuci tangan 6 langkah dengan baik dan benar. Menurut (Kementrian Kesehatan Republik Indonesia, 2020), untuk mencegah penularan COVID-19 dengan mencuci tangan 6 langkah dan menggunakan hand sanitizer. Peserta semua kelompok saat pretest juga mengetahui Covid-19 menyerang sistem 
pernapasan. Menurut Artayasa, (2021), virus Covid-19 menyerang sistem pernapasan menyebabkan gangguan pneumonia akut sampai dengan kematian. Peserta juga mengetahui menggunakan masker saat keluar rumah atau berpergian dapat mencegah penularan Covid-19. Menurut (World Health Organization, 2020), sifat utama COVID-19 adalah penyakit saluran pernapasan. Sehingga itu penggunaan masker saat keluar rumah adalah bagian dari rangkaian langkah pencegahan dan pengendalian yang dapat membatasi penyebaran COVID-19.

Seluruh peserta semua kelompok saat paham bahwa menurut Santuan Tugas Penanganan COVID-19 (2021), sesuai aturan pemerintah orang yang melakukan perjalanan dari luar kota wajib melakukan isolasi mandiri selama 2 minggu dan melakukan tes PCR atau Rapid Antigen Covid-19. Peserta mengetahui bahwa Covid-19 adalah penyakit menular dan dapat menular saat berbicara tanpa masker. Menurut Sukur dkk. (2020), Covid-19 adalah penyakit menular yang disebabkan oleh corona virus. Wulandari dkk. (2020), menjelaskan Covid-19 merupakan penyakit menular, penularan melalui kontak dekat dan drouplet sehingga saat berbicara dengan orang yang positif COVID-19 tidak menggunakan masker berisiko terinfeksi COVID-19.

Saat posttest, seluruh peserta kelompok intervensi mampu mengetahui pencegahan Covid-19 dapat dilakukan dengan menjaga jarak 1,5-2 meter. Supriyadi dkk (2020), menjelaskan pencegahan COVID-19 dapat dilakukan dengan menjaga jarak dengan orang lain minimal 1-2 meter. Peserta paham bahwa informasi yang baik dan benar tentang COVID-19 bermanfaat untuk semua orang. Menurut (Kementrian Kesehatan Republik Indonesia, 2020), informasi terkait COVID-19 adalah poin terpenting dan bermanfaat untuk semua orang sehingga dapat mencegah COVID-19.

Setelah diberikan pendidikan kesehatan seluruh peserta kelompok intervensi mengetahui bahwa orang telah sembuh dari COVID-19 dapat terserang COVID19 kembali. Menurut (Kementerian Kesehatan Republik Indonesia., 2020), orang yang sudah pernah menderita COVID-19 dapat terkena lagi, karena anti bodi yang dihasilkan pada saat positif tidak berkembang dengan baik. Orang yang pernah terinfeksi penyakit, pada tubuhnya akan terproduksi anti bodi untuk kekebalan tubuh. Sebanyak 95\% tubuh setelah menderita COVID-19 akan menghasilkan antibodi. Akan tetapi, seiring berjalannya waktu, jumlah antibody akan menurun dan tidak bertahan lama.

Tabel 3 Sikap tentang Pencegahan COVID-19

\begin{tabular}{lccccc}
\hline \multicolumn{1}{c}{ Sikap } & $\Sigma$ & Min & Max & Mean & SD \\
\hline Kelompok Kontrol & & & & & \\
Pretest & 21 & 39,00 & 56,00 & 48,95 & 4,29 \\
Posttest & 21 & 40,00 & 55,00 & 49,23 & 3,91 \\
\hline Kelompok Intervensi & & & & & \\
Pretest & 21 & 38,00 & 55,00 & 48,23 & 3,91 \\
Posttest & 21 & 40,00 & 56,00 & 48,28 & 4,64 \\
\hline
\end{tabular}


Berdasarkan tabel 3 diketahui rata-rata sikap pretest kelompok kontrol dan intervensi yaitu 48,95 dan 48,23. Sikap pretest pada penelitian ini yaitu suatu kemampuan siswa untuk menanggapi dan merespon tentang pencegahan COVID19. Sikap merupakan reaksi atau respon yang masih tertutup pada seseorang terhadap suatu stimulus atau objek (Notoatmodjo, 2010). Sikap seseorang dipengaruhi oleh pengalaman pribadi dan pengaruh orang yang dianggap penting. Tanggapan merupakan salah satu dasar untuk membentuk sikap seseorang. Pengalaman menjadi sesuatu yang mempengaruhi tanggapan seseorang. Orang yang mempunyai pengalaman akan cenderung bersikap positif, sedangkan tidak adanya pengalaman akan membentuk sikap negative tentang suatu obyek (Azwar, 2020). Responden yang memiliki sikap negatif dapat disebabkan belum mengetahui informasi mengenai pencegahan COVID-19. Hal tersebut sesuai bahwa informasi yang telah didapat oleh seseorang dapat menyebabkan sikap terhadap obyek menjadi positif (Azwar, 2016).

Tabel 4 Perbedaan Pengetahuan tentang COVID-19

\begin{tabular}{lccc}
\hline \multirow{2}{*}{ Kelompok } & \multicolumn{2}{c}{ Pengetahuan } & \multirow{2}{*}{ P-value } \\
\cline { 2 - 3 } & Mean & Selisih Mean & \\
\hline Kelompok Kontrol & & & \\
Pretest & 15,09 & 0,48 & 0,390 \\
Posttest & 15,57 & & \\
\hline Kelompok Intervensi & & & \multirow{2}{*}{0,009} \\
Pretest & 15,04 & 0,19 & \\
Posttest & 15,23 & & \\
\hline
\end{tabular}

Tabel 4 diketahui selisih mean pengetahuan pretest dan posttest pada kelompok kontrol sebesar 0,48 dan p-value adalah 0,390 (>0,05), maka dapat disimpulkan bahwa tidak ada perbedaan terhadap pengetahuan pencegahan COVID-19 antara pre-test dan post-test kelompok kontrol pada siswa SMP Negeri 2 Depok Sleman. Kelompok control merupakan kelompok yang tidak diberi perlakuan apapun, sehingga hasil pengukuran saat pretest dan posttest menunjukkan tidak adanya pengaruh atau perbedaan (Sugiyono, 2010). Meskipun begitu, ditinjau dari selisih mean terlihat adanya peningkatan rata-rata skor pengetahuan tentang pencegahan COVID-19 saat posttest pada kelompok kontrol. Adanya kenaikan nilai rata-rata ini kemungkinan disebabkan adanya responden yang masih mengingat pertanyaan saat pretest dan mencari jawaban. Pengalaman saat menjawab soal pretest menjadi menjadi dasar untuk peserta meningkatkan rasa percaya diiri saat menjawab kuesioner posttest (Fauziah, 2012).

Tabel 4 juga diketahui selisih mean pengetahuan pencegahan COVID-19 pada kelompok intervensi yaitu 0,19 p-value adalah 0,009 $(<0,05)$. Data menunjukkan bahwa pendidikan kesehatan efektif meningkatkan pengetahuan pencegahan COVID-19 di siswa SMP Negeri 2 Depok Sleman. Pendidikan kesehatan dipilih sebagai salah satu metode untuk meningkatkan pengetahuan 
dengan tujuan utama yaitu menuju hidup sehat. Pengetahuan yang didapat digunakan untuk mengubah individu dan masyarakat menjadi perilaku hidup sehat (Depkes RI, 2005). Penelitian ini sejalan dengan penelitian yang dilakukan Yusriani \& Agustini (2021), bahwa terdapat perbedaan tingkat pengetahuan dan sikap tindakan dalam mencegah penularan COVID-19. Usia, pendidikan, status ekonomi dan sumber informasi merupakan faktor yang dapat mempengaruhi pengetahuan seseorang. Sumber informasi menjadi media perantara dalam memperoleh pengetahuan. Jumlah dan luasnya sumber informasi menjadi penentu pengetahuan yang diperoleh. Sumber pengetahuan dapat didapat dari keluarga, teman, dan media sosial (Ariani, 2014).

Tabel 5 Perbedaan Sikap tentang Pencegahan COVID-19

\begin{tabular}{lccc}
\hline \multirow{2}{*}{ Kelompok } & \multicolumn{2}{c}{ Sikap } & \multirow{2}{*}{ P-value } \\
\cline { 2 - 3 } & Mean & Selisih Mean & \\
\cline { 2 - 3 } Kelompok Kontrol & & & \\
Pretest & 49,95 & $-1,72$ & 0,012 \\
Posttest & 48,23 & & \\
\hline Kelompok Intervensi & & & 0,002 \\
Pretest & 48,23 & 1,05 & \\
Posttest & 49,28 & & \\
\hline
\end{tabular}

Tabel 5 diketahui selisih mean sikap pretest dan posttest pada kelompok kontrol yaitu $-1,72$ p-value (>0,05), maka dapat disimpulkan bahwa tidak ada perbedaan terhadap sikap pencegahan COVID-19 antara pretest dan posttest kelompok kontrol pada siswa SMP Negeri 2 Depok Sleman. Kurangnya informasi tentang pencegahan COVID-19 menjadi salah satu penyebab responden tidak mengetahui jawaban dari pertanyaan yang diajukan. Hasil sejalan dengan Warto (2012), dengan hasil tidak terdapat perubahan sikap pada kelompok kontrol saat pretest dan posttest. Hal ini disebabkan karena sikap responden berbeda dengan lainnya, sikap juga memiliki tingkatan seperti menerima, menghargai, merespon dan bertanggung jawab (Wawan \& Dewi, 2010).

Tabel 5 diketahui selisih mean kelompok intervensi yaitu 1,05 dan p-value adalah 0,002 $(<0,05)$, maka dapat disimpulkan ada pengaruh pendidikan kesehatn terhadap sikap pencegahan COVID-19 pada posttest kelompok intervensi siswa SMP Negeri 2 Depok Sleman. Perubahan sikap menunjukkan hasil lebih baik dibanding sebelum diberikan pendidikan kesehatan. Peserta menerima hal-hal yang berkaitan dengan COVID-19 setelah diberikan pendidikan kesehatan. Hasil mendukung Fatmawati (2010), bahwa sikap siswa SMAN 8 Surakarta menjadi lebih baik setelah diberikan pendidikan kesehatan. Unsur komunikasi dalam pendidikan kesehatan berperan dalam mengubah sikap dan keyakinan pada proses pendidikan kesehatan.

Dari hasil penelitian menunjukkan ada perubahan sikap responden yang meningkat setelah peneliti memberikan Pendidikan kesehatan tentang pencegahan COVID-19. Sesuai pendapat Wahit, M,I \& Nurul (2007), pendidikan kesehatan 
menjadi media untuk mengubah perilaku mulai dari individu, kelompok, dan masyarakat supaya lebih mandiri mencapai tujuan hidup sehat. Pendapat lain dari Wawan \& Dewi (2010), bahwa sikap mempunyai tingkatan seperti tingkatan menerima, menghargai, merespon dan bertanggung jawab.

Hasil ini juga sesuai dengan teori Notoatmodjo (2010), pendidikan kesehatan mempunyai tujuan jangka pendek (immediate impact) untuk mengubah atau meningkatkan pengetahuan yang berdampaik baik pada sikap masyarakat. Tujuan penyuluhan lain berupa keinginan mencapai pengertian, maka cukup disampaikan mengucapkan pesan tersebut. Apabila tujuan adalah mengembangkan sikap menjadi positif maka sasaran harus mempunyai kesempatan untuk mencoba. Pendidikan kesehatan dapat meningkatkan sikap dikarenakan pendidikan kesehatan yang berupaya untuk mempengaruhi individu maupun kelompok sehingga dapat melakukan apa yang diharapkan. Pendidikan kesehatan merupakan bagian dari upaya kesehatan, dimulai dari promotif sampai dengan rehabilitatif. Pendidikan kesehatan berperan dalam meningkatkan sikap seseorang di setiap aspek upaya kesehatan.

Tabel 6 Sikap tentang Pencegahan COVID-19 Pretest dan Posttest Pada Siswa SMP Negeri 2 Depok Sleman

\begin{tabular}{lcccc}
\hline \multicolumn{1}{c}{ Nilai } & $\begin{array}{c}\text { Kelompok } \\
\text { Kontrol }\end{array}$ & $\begin{array}{c}\text { Kelompok } \\
\text { Intervensi }\end{array}$ & $\begin{array}{c}\text { Selisih } \\
\text { Mean }\end{array}$ & P-value \\
\hline Pengetahuan & & & & \\
Mean Pretest & 15,05 & 15,10 & 0,05 & 0,359 \\
Mean Posttest & 15,24 & 15,54 & 0,03 & 0,002 \\
Sikap & & & & \\
Mean Pretest & 48,29 & 48,28 & 0,19 & 0,349 \\
Mean Posttest & 48,24 & 48,95 & 0,71 & 0,001 \\
\hline
\end{tabular}

Berdasarkan Tabel 6 perbandingan pretest pengetahuan antara pada kelompok intervensi dan kelompok kontrol menunjukkan $p$-value 0,359 $(>0,05)$, hasil menunjukkan tidak ada perbedaan di antara kedua kelompok. Data pengetahuan pretest di kedua kelompok tersebut homogeny. Uji beda posttest pengetahuan di kedua kelompok menunjukkan p-value 0,002 $(<0,05)$, maka dapat disimpulkan bahwa ada perbedaan pengetahuan antara posttest kelompok kontrol dan kelompok intervensi. Kelompok intervensi mempunyai nilai rata-rata pengetahuan lebih tinggi saat posttest dibandingkan dengan kelompok kontrol.

Posttest pengetahuan kelompok kontrol dan kelompok intervensi ada perbedaan nilai mean sesudah diberikan intervensi terlihat lebih tinggi pada kelompok intervensi hal ini terjadi karena pada kelompok kelompok intervensi diberikan Pendidikan kesehatan. Menurut (Notoatmodjo, 2003) peningkatan tingkat pengetahuan pada post-test kelompok intervensi dikarenakan diberikan Pendidikan kesehatan. Informasi atau penyuluhan yang disampaikan ini membantu peneliti dalam menyampaikan materi tersebut agar terlihat perhatian pada responden. 
Tabel 6 juga diketahui hasil uji beda Posttest sikap pada kelompok kontrol dan kelompok intervensi menunjukkan p-value adalah 0,001 $(<0,05)$, maka dapat disimpulkan bahwa ada perbedaan sikap antara posttest kelompok kontrol dan kelompok intervensi posttest sikap kelompok kontrol dan Posttest sikap kelompok intervensi ada perbedaan nilai mean sesudah diberikan intervensi terlihat lebih tinggi pada posttest kelompok intervensi hal ini terjadi karena pada kelompok kelompok intervensi diberikan Pendidikan kesehatan. Menurut Supardi Sudibyo(2002), peningkatan sikap post-test kelompok intervensi karena diberikan Pendidikan kesehatan kesehatan. Pendidikan kesehatan atau edukasi kesehatan mampu meningkatkan kesadaran sikap seseorang tentang bagaimana pencegahan COVID-19.

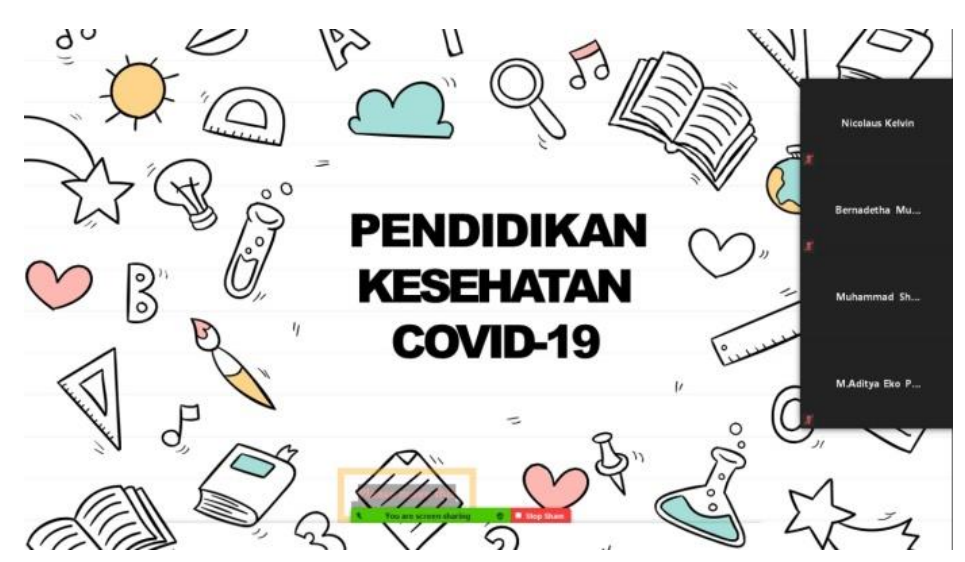

Gambar 1. Dokumentasi Pelaksanaan Pendidikan Kesehatan 1

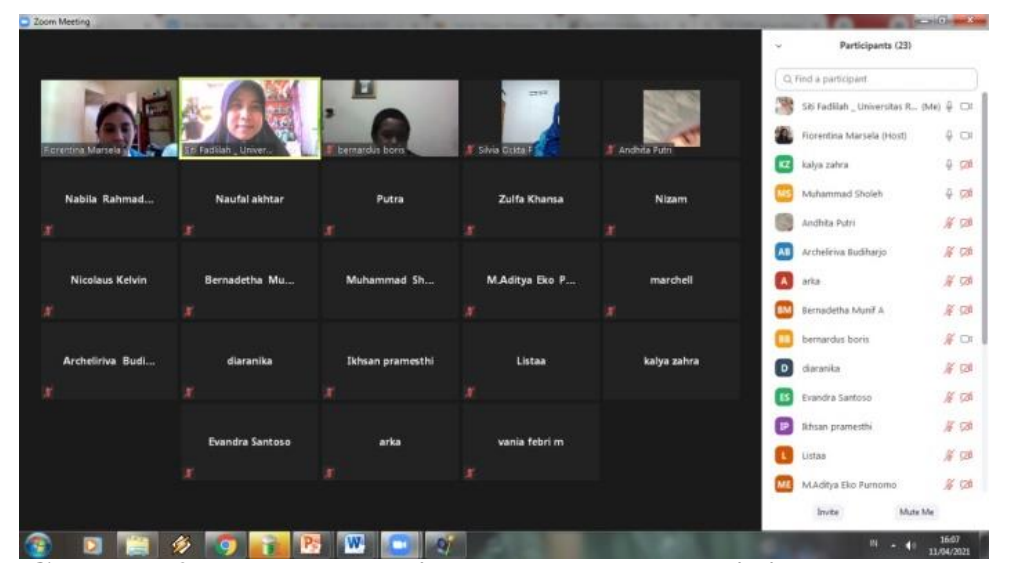

Gambar 2. Dokumentasi Pelaksanaan Pendidikan Kesehatan 2

\section{Kesimpulan}

Hasil menunjukkan terdapat peningkatan rata-rata pengetahuan dan sikap saat pretest dan posttest baik kelompok kontrol maupun kelompok intervensi. Hasil menunjukkan tidak ada perbedaan antara pretest dan posttest pada kelompok kontrol, sedangkan pada kelompok intervensi menunjukkan perbedaan yang signifikan. Hal ini terbukti bahwa pemberian pendidikan kesehatan efektif 
meningkatkan pengetahuan dan sikap tentang pencegahan Covid-19 Pada Siswa SMP Negeri 2 Depok Sleman.

\section{Daftar Pustaka}

Azwar, S. (2016). Sikap Manusia Teori dan Pengukurannya. Pustaka Pelajar.

Ariani. (2014). Aplikasi Metodologi Penelitian Kebidanan Pengetahuan Kesehatan Reproduksi. Yogyakarta: Nuha Medika

Depkes RI. (2005). Undang-Undang Republik Indonesia Nomor : 23 tahun 2005 Tentang Kesehatan.

Fatmawati. (2010). Pengaruh Pendidikan Kesehatan tentang Penyakit Menular Seksual terhadap Perubahan Pengetahuan dan Sikap Siswa SMA N 8 Surakarta.

Fauziah. (2012). Pengaruh Pendidikan Kesehatan Tentang Nutrisi Prakonsepsi Terhadap Tingkat Pengetahuan, Sikap, Dan Praktik Konsumsi Makanan Sehat Wanita Pranikah (Tesis (Ed.)). Universitas Indonesia.

I Nyoman Artayasa. (2021). Kebijakan Pemerintah Dalam Percepatan Penanganan Dampak COVID-19 Di Kota Denpasar. Jurnal Cakrawati, Vol. 03. No. 02.

Kementerian Kesehatan Republik Indonesia. (2020). Infeksi Emerging. https://infeksiemerging.kemkes.go.id/

Kementrian Kesehatan Republik Indonesia. (2020). KMK No. HK.01.07MENKES-413-2020 tentang Pedoman Pencegahan dan Pengendalian COVID-19 (pp. 31-34).

Notoatmodjo. (2003). Pendidikan dan Perilaku Kesehatan. Rineka Cipta.

Notoatmodjo, S. (2007). Promosi Kesehatan dan Ilmu Perilaku. Rineka Cipta.

Notoatmodjo, S. (2010). Ilmu Perilaku Kesehatan. Rineka Cipta.

Pratama, R. E., \& Mulyati, S. (2020). Pembelajaran Daring dan Luring pada Masa Pandemi Covid-19. Gagasan Pendidikan Indonesia, 1(2), 49. https://doi.org/10.30870/gpi.v1i2.9405

Sestiono Mindiharto. (2020). Virus COVID-19: Penyebab dan Penyembuhan. Universitas Muhammadiyah Gresik.

Sugiyono. (2010). Metode Penelitian Pendidikan Pendekatan Kuantitatif, kualitatif, dan $R \& D$. ALFABETA.

Susilo, A., Rumende, C. M., Pitoyo, C. W., Santoso, W. D., Yulianti, M., Herikurniawan, H., Sinto, R., Singh, G., Nainggolan, L., Nelwan, E. J., Chen, L. K., Widhani, A., Wijaya, E., Wicaksana, B., Maksum, M., Annisa, F., Jasirwan, C. O. M., (2020). Coronavirus disease 2019: Tinjauan literatur terkini. Jurnal Penyakit Dalam Indonesia, 7(1), 45-67 
Supardi Sudibyo, Ondri, M. (2002). Pengaruh metode ceramah dan Media Leaflet

Terhadap Perilaku pengobatan sendiri yang Sesuai Aturan. Bul Penelitian Kesehatan, Vol. 30 no.

Supriyadi, Vita Maryah Ardiyani, Novita Dewi (2020). Gambaran Pelaksanaan Social Distancing Dan Protokol Kesehatan Dimasa Pandemi COVID-19 Pada Mahasiswa. Wiraraja Medika : Jurnal Kesehatan.

Usman, S., Budi, S., \& Nur Adkhana Sari, D. (2020). Pengetahuan Dan Sikap Mahasiswa Kesehatan Tentang Pencegahan Covid-19 Di Indonesia. / Jurnal Ilmu Keperawatan Dan Kebidanan, 11(2), 410-414. Pengetahuan Dan Sikap Mahasiswa Kesehatan Tentang Pencegahan Covid-19 Di Indonesia.

Wawan \& Dewi (2010). Teori \& Pengukuran Pengetahuan, Sikap, Dan Perilaku Manusia. Nuha Medika.

Wahit, M,I \& Nurul, C. . (2007). Promosi Kesehatan Sebuah Pengantar Proses Belajar Mengajar Dalam Pendidikan. Graha Ilmu.

Warto. (2012). Pengaruh Pendidikan Kesehatan tentang Pengendalian Vektor Penyakit Pes terhadap Tingkat Pengetahuan dan Sikap Warga dalam Upaya Pencegahan Penyakit Pes di Desa Jrakah Boyolali.

WHO. (2020). WHO Director-General's remarks at the media briefing on 2019nCov on. https://www.who.int/dg/speeches/detail/who-director-generalsremarks-at-media-briefing-on-2019-ncov-on-11-february-2020

Witono\&Suparna. (2020). Kepesertaan Keluarga Berencana Pada Masa Awal Pandemi Covid-19 di Daerah Istimewa Yogyakarta. Jurnal Kependudukan, Keluarga Dan Sumber Daya Manusia, 1(2), 77-88. https://doi.org/10.37269/pancanaka.v1i2.47

Yogyakarta Tanggap COVID. (2020).

Yusriani, Y., \& Agustini, T. (2021). Edukasi Melalui Media Video Meningkatkan Pengetahuan, Sikap Dan Tindakan Siswa Dalam Mencegah Penularan Covid19. Konferensi Nasional Pengabdian http://conference.unisma.ac.id/index.php/KOPEMAS/KOPEMAS/paper/vie w/818 